\title{
Does public financial support stimulate innovation and productivity? An impact evaluation
}

\author{
Diego Aboal and Paula Garda
}

ABSTRACT

This paper contributes to the empirical literature that evaluates the effects of public financial support to innovation on innovation expenditures, innovation itself and productivity in developing countries. Propensity score matching techniques and data from Innovation Surveys are used to analyse the impacts of public financial support to innovation on Uruguayan firms. The results indicate that there is no crowding-out effect of private innovation investment by public funds and that public financial support in Uruguay seems to increase private innovation expenditures. Financial support also appears to induce increased research and development expenditures and innovative sales, with these effects being greatest for service firms. Public funds do not, however, significantly stimulate private expenditures by firms that would have carried out innovation activities even in the absence of financial support. conducts research, and a professor with ORT University and the Faculty of Economic Sciences and Administration of the University of the Republic, Montevideo, Uruguay. aboal@cinve.org.uy

Paula Garda is a researcher and economist at the Centre for Economic Research (cInve), Montevideo, and at the Organization for Economic Cooperation and Development (oECD), Paris, France.pgarda@cinve.org.uy 


\section{I}

\section{Introduction}

The idea that there is a need for public support to innovation, and public financial support in particular, rests on the assumption that innovation is a non-rival good (i.e. that it can be used by multiple firms) and cannot be fully protected because its output is basically knowledge (i.e. ways of producing new or improved goods or services), most of which is tacit (i.e. uncodified). Therefore, firms cannot fully internalize the return to their innovation investment. In other words, there is a problem of positive externalities for innovation. This creates a gap between the social and the private return on innovation, and consequently firms tend to underinvest relative to the social optimum.

As noted by Hall and Lerner (2010), there is evidence that imitations are not free, and in fact can cost between $50 \%$ and $75 \%$ of the original research and development (R\&D) investment. This can mitigate the above-mentioned externality problem, but it persists because the returns are not fully internalized by the original investor. Moreover, this available evidence is for manufacturing. We believe the problem affects service innovations even more than those in manufacturing because service innovations rely less on codified knowledge (which can be more easily protected), and the costs of imitation are presumably lower for innovations of this type.

The argument for public financial support goes beyond the externality problem mentioned above. Even if this problem can be solved with intellectual property protection, there are other characteristics of innovation investment that justify public financial support. In particular, innovation investment is highly uncertain and the information asymmetry between the innovator and the investor could be greater than with other types of investment, leading to larger problems of moral hazard and adverse selection. ${ }^{1}$ Therefore, credit constraints and high borrowing costs are likely to affect the level of innovation investment and consequently the

$\square$ Financial support from the Inter-American Development Bank is gratefully acknowledged. We wish to thank Gustavo Crespi and Marcelo Perera for their comments and suggestions. Maren Vairo provided excellent research assistance. The views expressed in this paper are the author's and are not necessarily shared by OECD or its member countries.

1 Given that the innovator has more information about the project than the investor, the innovator can use this advantage to increase his profit to the detriment of the investor. amount of innovation. The intangible characteristics of services and the non-technological and relatively ad hoc characteristics of many innovations in the service sector make these problems even more challenging there than in manufacturing.

These theoretical considerations have stimulated public intervention in different countries with the objective of increasing innovation investment, innovation itself and productivity. But of course, there are a number of reasons why R\&D and innovation policies more generally could fail to have positive or significant effects on productivity at the firm and aggregate level. Andrews and Criscuolo (2013) mention the following. First, R\&D and innovation policies could lead to an increase in the cost of innovation (e.g. through increases in scientists' pay). Second, innovation incentives could lead to duplication or the relabelling of existing non-innovation activities as innovation activities. Third, innovation agencies may have a limited ability to direct funds to the projects with the highest impact on productivity. Finally, incentives are sometimes taken up by firms that are less likely to generate spillovers and aggregate productivity gains. The existence of these interventions and the uncertainty about their effects meant that there was a need to evaluate their impacts.

So far, most of the available empirical literature has focused on public financial support policies for $\mathrm{R} \& \mathrm{D}$ activities and their impact on R\&D expenditures. As pointed out by Hall and Lerner (2010), the focus on R\&D instead of the broader concept of innovation investment is largely due to considerations of measurement feasibility and data availability. In addition, most of the available evidence does not distinguish between manufacturing and services, and in fact most papers deal with the manufacturing sector only. The potential positive effects of public support could be even greater for services than for manufacturing, not only for the reasons given above, but also because the service sector represents more than $70 \%$ of gross domestic product (GDP) in advanced economies and more than $60 \%$ in less developed economies. Therefore, the service sector is crucial to countries' aggregate productivity and needs to be better understood. Finally, most of the studies available are for Organization for Economic Cooperation and Development (OECD) or European countries, and thus evidence is lacking for less developed economies. 
This paper aims to help fill some of these gaps by evaluating the impact of public financial support on innovation in a developing country. Quasi-experimental methods and Innovation Survey data from Uruguay are used.

This paper contributes to the literature in three ways. First, it evaluates the effects of public financial support to innovation on innovation expenditures, innovation itself and productivity, thus extending research beyond the R\&D context. Second, it analyses the possible heterogeneity of the effects on services and manufacturing. Finally, the evaluation is based on data from a developing Latin American country, where empirical evidence is scarce.

The findings showed no crowding-out effect, either full or partial, between public and private innovation expenditures. Moreover, there is evidence of a crowding-in effect and of positive effects on innovation (measured by the percentage of innovative sales). Firms that received financial support increased their ratio of $\mathrm{R} \& \mathrm{D}$ expenditures to total innovation expenditure relative to those that did not. There were no effects on productivity or patent applications, probably due to the short time frame in which the evaluation was conducted. We found similar, but not identical, effects when we analysed the service and manufacturing sectors separately. While there was no crowding-out effect in either sector, we found that public financial support stimulated private innovation expenditures only in manufacturing. Productivity increased in service firms. Public funds did not, however, significantly stimulate private expenditures by firms that would have carried out innovation activities even in the absence of financial support.

This paper is organized as follows. Section II discusses the available evidence on public financial support and innovation in developing countries. Section III describes the empirical strategy and data. Section IV presents the main results. Section V reports the conclusions.

\section{II}

\section{Public financial support and innovation: the available evidence}

Most of the available evidence is for developed countries and manufacturing firms, and uses R\&D expenditures as the outcome variable. David, Hall and Toole (2000) extensively surveyed this literature, finding substitution effects between public and private $R \& D$ in one third of the studies analysed. More recent studies have focused mostly on matching methodologies to evaluate the crowding-out effect. With this approach, different studies have found that public financial support stimulates privately financed R\&D, so the crowding-out hypothesis is rejected. Examples are Almus and Czarnitzki (2003), who use data from a survey of German manufacturing firms; Duguet (2004), who uses a pool of French R\&Dperforming firms; and González and Pazó (2008), who use a sample of Spanish firms to evaluate the effect of subsidies. As for the service sector, Czarnitzki and Fier (2002) found that financial support stimulated private expenditures on innovative activities by studying a panel of German service firms. However, there are no studies that we know of that allow for direct comparison of the impact that a certain policy has on the service and manufacturing sectors.
As for evidence regarding the impact of policy on innovation (rather than on R\&D and innovation efforts which are inputs for innovation), Aerts and Czarnitzki (2004) found no significant effects of public support to innovation on patent applications from a survey of Flemish firms. Czarnitzki and Hussinger (2004) found that the impact on this variable was positive for a set of German manufacturing firms, and Czarnitzki, Hanel and Rosa (2011) found a positive impact on the number of new products introduced by Canadian manufacturing firms.

Evidence regarding the impact on firm performance, particularly productivity, is scarcer. Czarnitzki, Hanel and Rosa (2011) found that the impact on firms' profitability was not significant, while Wallsten (2000) found no significant impact on employment for small American high-technology firms. This may be because such policy effects often do not arise until several years after policy implementation, and thus the results may not have been observed over the short periods of analysis. On a different note, Lokshin and Mohnen (2013) found that fiscal incentives did have a positive impact on the wages of R\&D workers at Dutch firms. 
The evidence available for the effects of public financial support on innovation is scarce in emerging and developing countries. A few examples can be found in Crespi, Maffioli and Meléndez (2011), Hall and Maffioli (2008) and López-Acevedo and Tan (2010).

Crespi, Maffioli and Meléndez (2011) evaluated the effects of financial incentives for $\mathrm{R} \& \mathrm{D}$ (matching grants and contingent loans) provided by the Administrative Department of Science, Technology and Innovation (COLCIENCIAS) in Colombia on a beneficiary firm's economic performance. Using a dataset that allowed for analysis of long-term effects, the authors found that public funding from COLCIENCIAS had a significant impact on firm performance. More precisely, they found that new product introduction and labour productivity increased by about $12 \%$ and $15 \%$, respectively, with these effects becoming more significant between three and five years after the firms began to receive the funding.

Hall and Maffioli (2008) synthesized the results of a number of evaluations of technology development funds (TDFs) in Argentina, Brazil, Chile and Panama. The authors evaluated TDF recipients using data from innovation and industrial surveys. They found that TDFs did not crowd out R\&D funding from private sources and that they had a positive impact on the intensity of R\&D. Also, although low-cost credit had a more positive effect than matching grants on R\&D projects, suggesting that different types of financing affected firms differently, matching grants were more effective for new innovators. The authors also found that participating in a TDF resulted in a more proactive attitude towards innovation strategy. Although Argentina and Brazil were not included in this part of the study, when the authors took a firm's willingness to engage with external financing and knowledge sources as proxies for innovation strategy shifts, they found that TDFs had a positive effect on innovation. Conversely, participation in a TDF did not positively affect patent grants or new product sales, which were used as measures of innovative output, although the authors noted that the time frame may have been too short for the full effects of TDF participation in this regard to be observed. Evidence concerning the potential effects on firm performance was not uniform, with TDF participation being found to positively impact firm growth but not firm productivity. The authors argued that this could be due to the short time frame in which the evaluations were conducted, and that additional impact evaluations based on longer-term panel data were needed to shed some light on long-run effects.

López-Acevedo and Tan (2010) evaluated small and medium-sized enterprise (SME) credit programmes in Chile, Colombia, Mexico and Peru. The authors found positive gains in labour productivity, sales and employment in Chile and higher value added, sales, exports and employment in Mexico. In Colombia, the results suggested positive effects on exports, R\&D investment and total factor productivity. Finally, in Peru the findings showed significant positive effects on sales and profits. Confirming the findings of Hall and Maffioli (2008), López-Acevedo and Tan (2010) noted that some of the estimated effects on firm performance did not materialize for several years.

Table A.1 in the annex summarizes the results of 26 impact evaluations.

\section{III}

\section{The empirical strategy and data}

\section{The empirical strategy}

The objective of this paper is to estimate the impact of public financial support on innovation expenditures, innovation itself and productivity. Since we cannot observe what would happen if the "treated" firms did not get such financial support (the counterfactual), a suitable proxy is required. Firms that did not get public financial support could be considered candidates for a comparison (or control) group; however, it is possible that these firms did not get support because of some characteristic that could also affect the outcome variables. For example, it could be more difficult for small firms to get public financial support, and we know that the size of firms affects innovation. Therefore, if the innovation performance of firms that got support is compared with that of firms that did not get support, firms that received financial support are likely to show more innovation, but this could simply be because they are bigger and not because of the public financial support.

Luckily, this problem can be circumvented by using certain assumptions. In this study, we used propensity 
score matching methods. ${ }^{2}$ The following briefly explains the rationale behind this strategy and makes some methodological decisions explicit.

One of the parameters of interest in this paper is:

$$
\tau_{\mathrm{ATT}}=E[Y(1) \mid D=1]-E[Y(0) \mid D=1]
$$

where $\tau_{\mathrm{ATT}}$ is the average treatment effect on the treated; $E[Y(1) \mid D=1]$ is the mean value of the outcome variable $Y(1)$ (e.g. innovation investment), given that the firms received public financial support; and $E[Y(0) \mid D=1]$ is the counterfactual (i.e. the expected value of outcome variable $Y(0)$ ) for the firms in the treatment group had they not received public financial support. $\mathrm{D}=1$ means that the firm belongs to the treatment group.

Unfortunately, we cannot observe the counterfactual. What we can observe is $E[Y(0) \mid D=0]$, which in this case is mean innovation investment at firms not belonging to the treatment group $(\mathrm{D}=0)$ and not receiving treatment. Of course, $E[Y(0) \mid D=0]$ need not be equal to $E[Y(0) \mid D=1]$, which means that a bias can be introduced into the estimation if it is used as a proxy for $E[Y(0) \mid D=1]$. Note that

$$
\begin{gathered}
\tau_{\mathrm{ATT}}=E[Y(1) \mid D=1]-E[Y(0) \mid D=1] \\
-E[Y(0) \mid D=0]+E[Y(0) \mid D=0],
\end{gathered}
$$

and therefore

$$
E[Y(1) \mid D=1]-E[Y(0) \mid D=0]=\tau_{\mathrm{ATT}}+\text { bias, }
$$

where bias $\equiv E[Y(0) \mid D=1]-E[Y(0) \mid D=0]$. As previously noted, if firms with particular characteristics tend to be selected for the treatment group and these characteristics affect outcomes, then there will be bias. Conversely, if assignment to the two groups is completely random, such bias should not be a concern. Because this condition does not normally hold for Innovation Survey data, a further step was needed.

Assuming the differences between the treated and control groups lie in observable characteristics (e.g. firm size or capital and knowledge intensity) that are not affected by the treatment, we can proceed to find firms that are similar on these characteristics in the two groups and compare them. The identification assumption is that, given a set of observable covariates $\mathrm{X}$ that are not affected by treatment, potential outcomes are independent

\footnotetext{
2 See Caliendo and Kopeinig (2008) and Crespi and others (2011)
} for very intuitive presentations of these methods. of treatment assignment, this being the unconfoundedness or conditional independence assumption. This implies that selection for the treatment group is only based on observable variables $\mathrm{X}$, which can be controlled for.

Usually, $\mathrm{X}$ is of high dimension. Hence, to deal with this dimensionality problem, propensity scores can be balanced. We can use the Xs to estimate the probability of selection for treatment $\mathrm{P}(\mathrm{D}=1 \mid \mathrm{X})=\mathrm{P}(\mathrm{X})$ - using a probit or logit model in the case of binary treatmentand use this probability to find similar firms in the two groups (treated and control).

The propensity score matching (PSM) estimator for the average treatment effect on the treated is

$$
\tau_{\mathrm{ATT}}^{\mathrm{PSM}}=E[Y(1) \mid D=1, P(X)]-E[Y(0) \mid D=0, P(X)] .
$$

Assuming conditional (on the propensity score $\mathrm{P}(\mathrm{X})$ ) independence of outcome variables with respect to treatment, this estimator is unbiased.

A further important condition for the use of PSM, besides the conditional independence assumption, is for there to be enough treated and control firms on the common support. More formally, we need $0<P(D=1 \mid X)<1$. This condition ensures that firms with the same values of $X$ have a positive probability of being both participants and non-participants, and we avoid predicting perfectly whether a firm belongs to the control or the treatment group.

The matching algorithm used in this work is nearest neighbour matching with replacement, using a caliper of $20 \%$ of the standard deviation as suggested in the literature. We use oversampling, taking advantage of the large number of potential controls in our sample. In particular, for each treated firm, we found the five nearest neighbours (matching partners) and compared them with the treated firm.

We combined the propensity score matching with Mahalanobis metric matching over size and sectoral dummies. Hence, a treated firm is matched with the closest control firm of the same sector and similar size using the Mahalanobis distance, which is a way to determine similarity between two random multidimensional variables. It differs from the Euclidean distance, in which the correlation between random variables is taken into consideration.

\section{Data}

We applied the above methodology to evaluate the effects of financial support granted to Uruguayan service and manufacturing firms during the period from 2004 to 2009. 
For this purpose, we used two rounds of the Innovation Survey: 2004-2006 and 2007-2009.

The Innovation Survey data were collected in parallel with those of the Economic Activity Survey, using the same sample and statistical framework. All firms with more than 49 workers were required to participate in these surveys. Firms with 20 to 49 employees and those with fewer than 19 were selected using simple random sampling within each economic sector at the International Standard Industrial Classification of All Economic Activities (ISIC) two-digit level up to 2005. From that point forward, random strata were defined for units with fewer than 50 workers within each economic sector at the IsIC four-digit level.

We matched the Innovation Surveys with the 2004 and 2007 Economic Activity Surveys because we needed information on firms' size at the beginning of the period, capital (fixed assets) and productivity. To avoid endogeneity problems associated with size, capital and productivity, we used these variables at the beginning of the period. All the other variables used in the empirical exercise came from the Innovation Survey. When matching was carried out with the Economic Activity Survey, some firms were lost because of sampling problems, so that the sample size was reduced when data collected from the Economic Activity Survey were used.

To reduce the loss of observations and recover the information for the missing variables at the beginning of the period in each survey, we used an imputation procedure based on a regression between log size $(\mathrm{t}-1)$ and age and sectoral dummies. We used this regression to predict size at $(t-1)$ for the missing observations. The same was done for capital stock and productivity. Note that this technique uses the information available at the beginning of the survey period, not the end, to avoid interaction between causal effects. However, for the sake of robustness, we presented the results with the reduced sample (i.e. without the imputation procedure).

For the service sector, the final number of firms included in the Innovation Survey was 1,868, with 885 being from the first survey and 983 from the second. For the manufacturing sector, the final number of included firms was 1,727, with 816 from the 2004-2006 survey and 911 from the 2007-2009 survey.

The treatment variable was financial support. The treatment group comprised those firms that received financial support. We considered a firm to be financially supported if it received some financial support from the public sector in the period of reference. The survey includes information on financial support to innovation received from the public sector, excluding public firms from the definition of the public sector. The Innovation Survey asks firms what percentage of innovation expenditure came from public sources. Therefore we know not only whether the firm received public financial support, but the amount of this support. In Uruguay, financial support is given mostly in the form of subsidies (matching grants). R\&D tax credits did not exist in the period considered in this research. Table A.2 in the annex shows the characteristics of some of the programmes supporting innovation in Uruguay.

In the first instance, we evaluated the effect of financial support on the innovation expenditure effort (expenditures on innovation over sales). Total innovation expenditures comprised investment in design, installation of machinery, industrial engineering, embodied and disembodied technology, marketing and training (we were able to distinguish between total and private innovation expenditures). Then, we analysed the effect of financial support on R\&D expenditures (both internal and external) over innovation expenditure, the share of innovative sales, patent applications and productivity. Productivity was defined as the logarithm of sales over total employment.

Table 1 reports the number of firms in each sector, divided into knowledge-intensive business services and traditional services, or high-technology and lowtechnology manufacturing sectors. Manufacturing-sector firms tend to invest more in innovation activities than service firms. The high-technology sector innovates the most, followed by knowledge-intensive business service sectors. The third column of the table shows the manufacturing bias of innovation policies. While more than $4 \%$ of the manufacturing firms received public financial support during 2004-2009, only $2 \%$ of the service firms obtained financial support.

Table 2 reports the innovation effort (innovation expenditures divided by sales) of firms with and without financial support. On average, firms in the manufacturing sector invested more in innovation activities than firms in the service sector. One fact to highlight is that in the manufacturing sector the private effort made by firms with financial support (column 2) was considerably greater than the effort by firms with innovation activities but without financial support (column 4). The difference averaged 0.9 percentage points for manufacturing firms, with the gap being largest in the high-technology sector at 1.77 percentage points. In the service sector, conversely, the private effort was smaller among firms 
receiving financial support than among those undertaking innovation activities without financial support, by an average of 0.7 percentage points. This difference was driven by traditional service firms. Knowledgeintensive business services with financial support made a larger private effort than those without it (a gap of 2.65 percentage points).

These raw data lead us to conclude that a crowdingout effect could exist in the service sector, but not in the manufacturing sector. Our empirical strategy seeks to disentangle whether this effect arises because public financial support tends to be directed to firms in the manufacturing sector that invest more rather than to firms in the service sector with poor innovation performance. This will be done by comparing firms with a similar likelihood of obtaining financial support.

Finally, table 3 presents the means of the selected matching variables for the control and treatment groups by sector. Firms in the treatment group tend to be larger than those in the control group. Also, firms in the treatment group tend to have obtained more patents than those in the control group. Firms in the treatment group tend to be located in Montevideo (the capital of the country), belong to networks, and have more outlets. With respect to age and ownership status, there are no clear differences.

TABLE 1

Firms with innovation activities and financial support, 2004-2009

(Number of observations and percentages)

\begin{tabular}{|c|c|c|c|}
\hline & Observations & $\begin{array}{l}\text { Proportion with } \\
\text { innovation activities }\end{array}$ & $\begin{array}{l}\text { Proportion with } \\
\text { financial support }\end{array}$ \\
\hline Services & 1868 & 38.5 & 2.1 \\
\hline Knowledge-intensive business services & 628 & 42.0 & 1.9 \\
\hline Traditional services & 1240 & 36.7 & 2.3 \\
\hline Manufacturing & 1727 & 42.3 & 4.2 \\
\hline High-technology & 399 & 52.4 & 5.8 \\
\hline Low-technology & 1328 & 39.3 & 3.7 \\
\hline
\end{tabular}

Source: prepared by the authors on the basis of the 2004-2006 and 2007-2009 Innovation Surveys conducted in Uruguay.

TABLE 2

Average innovation effort at firms with and without financial support, 2004-2009 (Percentages)

\begin{tabular}{|c|c|c|c|c|}
\hline & \multicolumn{2}{|c|}{ With support } & \multicolumn{2}{|c|}{ Without support } \\
\hline & Total & Private & All & $\mathrm{IE}>0$ \\
\hline Services & 6.37 & 3.62 & 1.61 & 4.33 \\
\hline Knowledge-intensive business services & 9.77 & 6.93 & 1.75 & 4.28 \\
\hline Traditional services & 4.91 & 2.21 & 1.54 & 4.35 \\
\hline Manufacturing & 7.50 & 5.05 & 1.66 & 4.16 \\
\hline High-technology & 6.27 & 5.07 & 1.64 & 3.30 \\
\hline Low-technology & 8.08 & 5.04 & 1.67 & 4.50 \\
\hline
\end{tabular}

Source: prepared by the authors on the basis of the 2004-2006 and 2007-2009 Innovation Surveys conducted in Uruguay. $\mathrm{IE}=$ innovation expenditure. 
Mean comparison of firms with and without financial support on selected controls (Numbers and percentages)

\begin{tabular}{|c|c|c|c|c|c|c|}
\hline & \multicolumn{2}{|c|}{ Services } & \multicolumn{2}{|c|}{$\begin{array}{l}\text { Knowledge-intensive } \\
\text { business services }\end{array}$} & \multicolumn{2}{|c|}{ Traditional services } \\
\hline & With & Without & With & Without & With & Without \\
\hline Size (log employees)(t - 1) & 4.48 & 3.85 & 4.11 & 3.87 & 4.64 & 3.84 \\
\hline Foreign-owned $^{\mathrm{a}}$ & 7.5 & 10.4 & 16.7 & 13.8 & 3.6 & 8.7 \\
\hline Age (years) & 23.9 & 18.3 & 11.6 & 13.7 & 29.4 & 20.7 \\
\hline Patents obtained ${ }^{\mathrm{a}}$ & 5.0 & 1.2 & 8.3 & 1.3 & 3.6 & 1.2 \\
\hline Network $^{\mathrm{a}}$ & 30.0 & 19.9 & 50.0 & 18.3 & 21.4 & 20.6 \\
\hline Group $^{\mathrm{a}}$ & 15.0 & 15.6 & 16.7 & 16.2 & 14.3 & 15.3 \\
\hline Outlets & 4.7 & 3.9 & 1.6 & 1.4 & 6.0 & 5.1 \\
\hline \multirow[t]{3}{*}{ In Montevideo $^{\mathrm{a}}$} & 85.0 & 74.3 & 100.0 & 87.2 & 78.6 & 67.8 \\
\hline & \multicolumn{2}{|c|}{ Manufacturing } & \multicolumn{2}{|c|}{ High-technology } & \multicolumn{2}{|c|}{ Low-technology } \\
\hline & With & Without & With & Without & With & Without \\
\hline Size $(\log$ employees $)(t-1)$ & 4.24 & 3.80 & 4.09 & 3.56 & 4.30 & 3.87 \\
\hline Foreign-owned $^{\mathrm{a}}$ & 9.7 & 11.5 & 8.7 & 17.3 & 10.2 & 9.9 \\
\hline Age (years) & 32.29 & 25.56 & 35.96 & 28.01 & 30.57 & 24.84 \\
\hline Patents obtained ${ }^{\mathrm{a}}$ & 2.8 & 2.7 & 0.0 & 3.2 & 4.1 & 2.5 \\
\hline Network $^{\mathrm{a}}$ & 16.7 & 7.9 & 17.4 & 10.1 & 16.3 & 7.2 \\
\hline Group $^{\mathrm{a}}$ & 18.1 & 13.2 & 8.7 & 16.0 & 22.4 & 12.4 \\
\hline Outlets & 1.85 & 1.74 & 1.57 & 1.60 & 1.98 & 1.79 \\
\hline In Montevideo ${ }^{\mathrm{a}}$ & 83.3 & 78.0 & 91.3 & 87.0 & 79.6 & 75.4 \\
\hline
\end{tabular}

Source: prepared by the authors on the basis of Innovation Surveys (2004-2006 and 2007-2009) conducted in Uruguay.

a Percentages.

\section{IV}

\section{Results}

Initially, the results for the complete sample of firms, including both manufacturing and service-sector firms, are presented together. To reduce endogeneity issues, the strategy is to match observations according to their pre-treatment behaviour. With this objective, the variables worked with are size, capital per worker and productivity at $\mathrm{t}-1$.

We also present results dividing the sample into manufacturing and service sector firms. We used two different groups of observations to select the controls for the average treatment effects on the treated estimator. First, we used the full sample, including observations for firms both with and without innovation expenditures. Second, we restricted the sample to observations with innovation activities. In the first case, we took into account the potential effect of financial support on the inducements to undertake innovation activities. In the second, we evaluated the stimulus of financial support for the effort, considering that all supported firms would have performed innovation activities in the absence of support.

\section{Complete sample results}

In the first stage, we investigated factors that influence the probability of receiving public financial support. The dependent variable took the value 1 if the firm received public funding and 0 if it did not. Table 4 displays marginal effects after probit estimation. The first column takes all firms as the possible control group, while the second column is restricted to firms that reported positive innovation expenditures.

The vector of explanatory variables includes firm characteristics that may influence the probability of getting public funds. We included firm size in a quadratic form, measured as the logarithm of the number of employees at 
TABLE 4

\begin{tabular}{|c|c|c|}
\hline & $\begin{array}{c}(1) \\
\text { All firms }\end{array}$ & $\begin{array}{l}(2) \\
\text { Innovative firms only }\end{array}$ \\
\hline Size $(t-1)$ & $\begin{array}{l}0.0408 * * * \\
(0.0147)\end{array}$ & $\begin{array}{l}0.0663^{*} \\
(0.0374)\end{array}$ \\
\hline Size $(t-1)$ squared & $\begin{array}{l}-0.00292 * \\
(0.00160)\end{array}$ & $\begin{array}{l}-0.00499 \\
(0.00396)\end{array}$ \\
\hline Foreign-owned & $\begin{array}{l}-0.0163 * * * \\
(0.00588)\end{array}$ & $\begin{array}{l}-0.0405 * * * \\
(0.0156)\end{array}$ \\
\hline Age & $\begin{array}{l}-0.000182 \\
(0.000287)\end{array}$ & $\begin{array}{l}-0.000475 \\
(0.000693)\end{array}$ \\
\hline Age squared & $\begin{array}{l}2.54 \mathrm{e}-06 \\
(2.66 \mathrm{e}-06)\end{array}$ & $\begin{array}{l}6.49 \mathrm{e}-06 \\
(6.22 \mathrm{e}-06)\end{array}$ \\
\hline Patents obtained & $\begin{array}{c}0.0129 \\
(0.0222)\end{array}$ & $\begin{array}{l}-0.00653 \\
(0.0327)\end{array}$ \\
\hline $\mathrm{K} / \mathrm{L}(\mathrm{t}-1)$ & $\begin{array}{l}-0.000361 \\
(0.00252)\end{array}$ & $\begin{array}{l}-6.85 \mathrm{e}-05 \\
(0.00532)\end{array}$ \\
\hline Productivity(t - 1) & $\begin{array}{c}0.00315 \\
(0.00362)\end{array}$ & $\begin{array}{l}-0.00434 \\
(0.00898)\end{array}$ \\
\hline Network & $\begin{array}{l}0.0123 \\
(0.00891)\end{array}$ & $\begin{array}{c}0.00562 \\
(0.0173)\end{array}$ \\
\hline Group & $\begin{array}{r}0.000225 \\
(0.00818)\end{array}$ & $\begin{array}{l}-0.00245 \\
(0.0193)\end{array}$ \\
\hline Outlets & $\begin{array}{l}-6.75 e-05 \\
(0.000152)\end{array}$ & $\begin{array}{l}-0.000243 \\
(0.000452)\end{array}$ \\
\hline Montevideo & $\begin{array}{c}0.00814 \\
(0.00638)\end{array}$ & $\begin{array}{c}0.0181 \\
(0.0163)\end{array}$ \\
\hline Industry dummies & Yes & Yes \\
\hline $\begin{array}{l}\text { Observations } \\
\text { Log likelihood }\end{array}$ & $\begin{array}{l}2914 \\
-423.1\end{array}$ & $\begin{array}{l}1382 \\
-356.4\end{array}$ \\
\hline
\end{tabular}

Source: prepared by the authors on the basis of Innovation Surveys (2004-2006 and 2007-2009) and Economic Activity Surveys conducted in Uruguay.

Note: standard errors in parentheses. $* * * \mathrm{p}<0.01 ; * \mathrm{p}<0.1$.

$\mathrm{t}$ - 1 , age (as a proxy for experience), a dummy variable for foreign ownership (when firms were more than 10\% foreign-owned), capital intensity (measured as fixed assets per worker) and productivity at $\mathrm{t}-1$. We also included dummies indicating whether the firm had obtained patents in the period of reference (as a proxy for past innovation effort), whether it belonged to a network or to a group of firms, whether it was located in Montevideo, how many outlets it had and how old it was, plus the quadratic form. The dummy for patents obtained is meant to control for persistence in innovation, since obtaining a patent is a long process and when a patent is obtained it is probably a consequence of past innovations. Finally, we included 33 sectoral dummies (at the two-digit level).

The results show that the most important determinant of the probability of receiving public funds is size: the larger the firm, the higher its probability of receiving public funds. Conversely, being foreign-owned decreases the probability of receiving public funds for innovation. These were the only two significant variables (with the exception of some sectoral dummies).
In accordance with our empirical strategy, the matching was done using the propensity score calculated. Hence, some important assumptions needed to be validated. The first requirement was to check the common support or overlap condition. For this purpose, we performed a visual analysis of the density distribution of the propensity scores in the two groups.

Figure 1 shows the propensity scores calculated for the treated and control groups. Observations are more left-skewed in the control group than in the treatment group, but a comparison of the minimum and maximum propensity scores leads to the conclusion that there is significant overlap. When firms with positive innovation expenditures are considered, some firms are found to be off common support. We restricted the estimation to the propensity score region of common support.

Finally, since we did not condition on all covariates but on the propensity score, it was necessary to check whether the matching procedure was balancing the distribution of the relevant variables in both the control and the treatment groups. 
FIGURE 1

Propensity scores of treated firms and potential controls for all firms (left panel) and firms with positive innovation expenditures only (right panel)

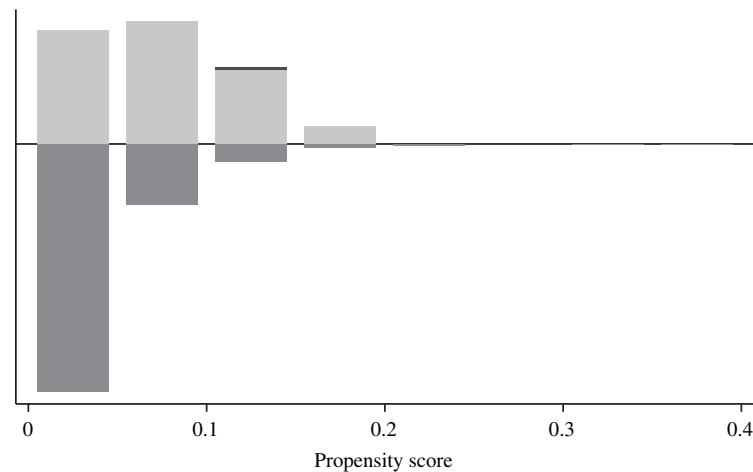

Untreated

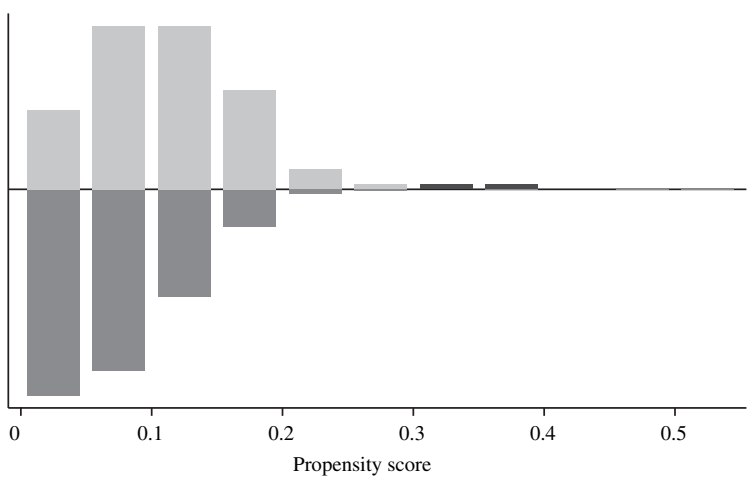

Treated: on support

Treated: off support

Source: prepared by the authors on the basis of Innovation Surveys (2004-2006 and 2007-2009) and Economic Activity Surveys conducted in Uruguay.

In table 5, the treated group appears to be different from the potential control groups on some relevant variables before the matching, but similarity between the treated and control groups is achieved after the matching. Table 5 also shows that the differences were significantly reduced and were not statistically significant.
Table 6 reports the results for the average treatment effect, considering the following performance variables: investment expenditures, private innovation effort, the share of R\&D in innovation expenditures, the share of innovative sales, patent applications and (log) productivity.

TABLE 5

Mean comparison of financially supported and non-supported firms on selected variables, before and after matching

\begin{tabular}{|c|c|c|c|c|c|c|c|c|c|c|c|c|c|}
\hline \multirow{3}{*}{ Variable } & & \multicolumn{6}{|c|}{ All firms in the potential control group } & \multicolumn{6}{|c|}{$\begin{array}{l}\text { Potential control group with positive } \\
\text { innovation expenditure }\end{array}$} \\
\hline & & \multicolumn{4}{|c|}{ Mean } & \multicolumn{2}{|c|}{ t-test } & \multicolumn{4}{|c|}{ Mean } & \multicolumn{2}{|c|}{ t-test } \\
\hline & & Treated & Control & $\%$ bias & $\begin{array}{l}\% \text { reduct } \\
\text { bias }\end{array}$ & $\mathrm{t}$ & $\mathrm{p}>\mathrm{t}$ & Treated & Control & $\%$ bias & $\begin{array}{l}\% \text { reduct } \\
\text { bias }\end{array}$ & $\mathrm{t}$ & $\mathrm{p}>$ \\
\hline \multirow[t]{2}{*}{ Size } & Unmatched & 4.34 & 3.84 & 46.2 & & 4.69 & 0.00 & 4.34 & 4.08 & 23.4 & & 2.27 & 0.02 \\
\hline & Matched & 4.35 & 4.28 & 6.5 & 85.9 & 0.52 & 0.61 & 4.37 & 4.28 & 7.7 & 66.8 & 0.61 & 0.54 \\
\hline \multirow[t]{2}{*}{ Foreign-owned } & Unmatched & 0.090 & 0.107 & -5.8 & & -0.58 & 0.56 & 0.09 & 0.16 & -20.7 & & -1.90 & 0.06 \\
\hline & Matched & 0.091 & 0.146 & -18.6 & -221 & -1.26 & 0.21 & 0.09 & 0.18 & -25.3 & -22 & -1.77 & 0.08 \\
\hline \multirow[t]{2}{*}{ Age } & Unmatched & 29.342 & 21.816 & 33.7 & & 3.90 & 0.00 & 29.15 & 24.80 & 18.6 & & 1.98 & 0.05 \\
\hline & Matched & 29.491 & 27.513 & 8.8 & 73.7 & 0.64 & 0.52 & 29.51 & 28.05 & 6.3 & 66.4 & 0.45 & 0.65 \\
\hline \multirow[t]{2}{*}{ Patents obtained } & Unmatched & 0.04 & 0.02 & 11.5 & & 1.43 & 0.15 & 0.04 & 0.04 & 0.3 & & 0.03 & 0.98 \\
\hline & Matched & 0.04 & 0.03 & 6 & 47.5 & 0.41 & 0.69 & 0.04 & 0.04 & -0.5 & -50.5 & -0.03 & 0.98 \\
\hline \multirow[t]{2}{*}{$\mathrm{K} / \mathrm{L}$} & Unmatched & 0.634 & 0.620 & 1 & & 0.08 & 0.94 & 0.64 & 0.73 & -5.1 & & -0.40 & 0.69 \\
\hline & Matched & 0.639 & 0.686 & -3.3 & -236.6 & -0.34 & 0.73 & 0.65 & 0.80 & -8.3 & -62.7 & -0.93 & 0.35 \\
\hline \multirow[t]{2}{*}{ Productivity $\mathrm{t}-1$} & Unmatched & 13.738 & 13.361 & 36.1 & & 3.59 & 0.00 & 13.74 & 13.67 & 6.5 & & 0.63 & 0.53 \\
\hline & Matched & 13.746 & 13.739 & 0.7 & 98 & 0.05 & 0.96 & 13.75 & 13.91 & -15.5 & -138 & -1.18 & 0.24 \\
\hline \multirow[t]{2}{*}{ Network } & Unmatched & 0.21 & 0.16 & 12 & & 1.31 & 0.19 & 0.20 & 0.22 & -5.6 & & -0.55 & 0.58 \\
\hline & Matched & 0.209 & 0.141 & 17.6 & -46.6 & 1.32 & 0.19 & 0.206 & 0.195 & 2.5 & 54.3 & 0.19 & 0.85 \\
\hline \multirow[t]{2}{*}{ Group } & Unmatched & 0.171 & 0.147 & 6.6 & & 0.70 & 0.48 & 0.165 & 0.200 & -8.9 & & -0.87 & 0.39 \\
\hline & Matched & 0.173 & 0.169 & 1 & 85.4 & 0.07 & 0.95 & 0.168 & 0.221 & -13.7 & -54.4 & -0.96 & 0.34 \\
\hline \multirow[t]{2}{*}{ Outlets } & Unmatched & 2.883 & 2.781 & 0.5 & & 0.04 & 0.97 & 2.917 & 3.982 & -3.9 & & -0.29 & 0.77 \\
\hline & Matched & 2.90 & 2.27 & 3.3 & -518.4 & 0.80 & 0.42 & 2.94 & 2.24 & 2.6 & 34.2 & 0.89 & 0.38 \\
\hline \multirow[t]{2}{*}{ In Montevideo } & Unmatched & 0.847 & 0.757 & 22.6 & & 2.18 & 0.03 & 0.853 & 0.796 & 15.1 & & 1.44 & 0.15 \\
\hline & Matched & 0.845 & 0.783 & 15.7 & 30.8 & 1.17 & 0.24 & 0.850 & 0.783 & 17.8 & -18 & 1.26 & 0.21 \\
\hline
\end{tabular}

Source: prepared by the authors on the basis of Innovation Surveys (2004-2006 and 2007-2009) and Economic Activity Surveys conducted in Uruguay. 
The results show that financial support had a stimulating effect on both private and total innovation expenditures. Financially supported firms invested $4.5 \%$ more of their sales in innovation than non-supported firms. This result indicates that not only is there no crowding-out effect, but that firms invested more from their own budgets.

Financially supported firms spent $8 \%$ more of their innovation expenditures on R\&D than control firms. This result was expected since financial support is usually directed to R\&D. It should be recalled that this sample includes all potential firms in the control group (i.e. it includes firms that may have zero innovation expenditures). Hence, this result can be interpreted as public financial support having inducement effects on innovation activities.

Receiving financial support significantly increased the share of innovative sales relative to firms in the control group.
Finally, receiving financial support had no statistically significant effect on productivity. This result is not surprising since we were looking at a very short time horizon, and effects on productivity can become apparent only much later. Probably for the same reason, the results show that there was no statistical effect on patent applications in the current period.

Table 7 presents the results for firms with positive investment only. They show that financial support had no stimulating effect on private investment, indicating that there was no crowding-in effect. Firms added the amount of subsidies to their private investment, not replacing private investment with public funds, but also not increasing their private innovation investment. The results show that financially supported firms made larger R\&D investments. On the other hand, there were no significant effects on the share of innovative sales, patent applications or productivity.

TABLE 6

Financial support effects

\begin{tabular}{|c|c|c|c|c|c|c|}
\hline & (1) & (2) & (3) & (4) & (5) & (6) \\
\hline Dependent variable & $\begin{array}{l}\text { Innovation } \\
\text { expenditure } \\
\text { effort }\end{array}$ & Private effort & $\mathrm{R} \& \mathrm{D}^{\mathrm{a}}$ & $\begin{array}{l}\text { Innovative } \\
\text { sales }^{\mathrm{b}}\end{array}$ & $\begin{array}{c}\text { Patent } \\
\text { applications }\end{array}$ & Productivity \\
\hline ATT & $\begin{array}{l}4.492 * * * \\
(1.230)\end{array}$ & $\begin{array}{l}1.922 * * \\
(0.850)\end{array}$ & $\begin{array}{l}8.242 * * * \\
(2.643)\end{array}$ & $\begin{array}{l}14.63 * * * \\
(4.306)\end{array}$ & $\begin{array}{c}0.0268 \\
(0.0263)\end{array}$ & $\begin{array}{l}0.123 \\
(0.0990)\end{array}$ \\
\hline Treated group & 110 & 110 & 110 & 110 & 110 & 110 \\
\hline Off support & 1 & 1 & 1 & 1 & 1 & 1 \\
\hline Potential control group & 2803 & 2803 & 2803 & 2803 & 2803 & 2803 \\
\hline
\end{tabular}

Source: prepared by the authors on the basis of Innovation Surveys (2004-2006 and 2007-2009) and Economic Activity Surveys conducted in Uruguay.

a Share of innovation expenditures that is R\&D.

b Share of sales due to innovation.

Note: bootstrapped standard errors in parentheses. 100 replications $* * * \mathrm{p}<0.01 ; * * \mathrm{p}<0.05$.

TABLE 7

The effects of financial support on firms with positive innovation expenditure

\begin{tabular}{|c|c|c|c|c|c|c|}
\hline & (1) & (2) & (3) & (4) & (5) & (6) \\
\hline & $\begin{array}{l}\text { Innovation } \\
\text { expenditure } \\
\text { effort }\end{array}$ & Private effort & $R \& D^{a}$ & $\begin{array}{l}\text { Innovative } \\
\text { sales }^{\text {b }}\end{array}$ & $\begin{array}{c}\text { Patent } \\
\text { applications }\end{array}$ & Productivity \\
\hline ATT & $\begin{array}{l}2.531 * * \\
(1.055)\end{array}$ & $\begin{array}{l}-0.107 \\
(0.937)\end{array}$ & $\begin{array}{l}5.427 * \\
(3.005)\end{array}$ & $\begin{array}{c}6.436 \\
(3.928)\end{array}$ & $\begin{array}{r}0.00561 \\
(0.0250)\end{array}$ & $\begin{array}{l}-0.0151 \\
(0.100)\end{array}$ \\
\hline Treated group & 107 & 107 & 107 & 107 & 107 & 107 \\
\hline Off support & 2 & 2 & 2 & 2 & 2 & 2 \\
\hline Potential control group & 1273 & 1273 & 1273 & 1273 & 1273 & 1273 \\
\hline
\end{tabular}

Source: prepared by the authors on the basis of Innovation Surveys (2004-2006 and 2007-2009) and Economic Activity Surveys conducted in Uruguay.

a Share of innovation expenditure that is R\&D.

b Share of sales due to innovation.

Note: bootstrapped standard errors in parentheses. 100 replications $* * \mathrm{p}<0.05 ; * \mathrm{p}<0.1$. 
To check the robustness of our results, we used the same methodology but without applying the imputation procedure. In this case, the treatment group comprised 80 firms, compared with 109 firms when the imputation procedure was used. The results shown in tables A.3 and A. 4 of the annex indicate that the findings were robust to the imputation procedure. Quantitative results were very similar, with the exception of the results for $R \& D$, where the impact was smaller when the imputation procedure was not followed.

To summarize, the conclusion from the results is that private funds were not crowded out by public funds. Also, public financing in Uruguay seems to induce some increase in private innovation effort, $R \& D$ and innovation expenditures, and has positive effects on sales derived from innovation. However, public funds do not seem to significantly stimulate private expenditures by firms that would have carried out innovation activities in the absence of subsidies. Finally, there were no effects on patent applications and productivity, probably because of the short time period in which the evaluation was conducted. In what follows, we distinguish between the service and manufacturing sectors.

\section{Results for the service and manufacturing sectors}

Because of the heterogeneities between service and manufacturing firms, and thence the different impact that financial support could have on each sector, this section presents results for the manufacturing and service sectors separately.

Table 8 reports the marginal effects of the probability of receiving public financial support. Size is still a very important determinant in the service sector, more than in the manufacturing sector. When the sample is restricted to firms that show positive innovation expenditures, size becomes statistically insignificant. In the manufacturing sector, being foreign-owned negatively affects the probability of being financially supported, while no other variable seems to have statistically significant effects on probability, except some of the sectoral dummies.

TABLE 8

\begin{tabular}{|c|c|c|c|c|}
\hline \multicolumn{5}{|c|}{ Propensity score estimates } \\
\hline \multirow{3}{*}{ Control group } & \multicolumn{2}{|c|}{ Services } & \multicolumn{2}{|c|}{ Manufacturing } \\
\hline & (1) & (2) & (3) & (4) \\
\hline & All & $\mathrm{IE}>0$ & All & IE $>0$ \\
\hline Size $(t-1)$ & $\begin{array}{l}0.00801 * * * \\
(0.00212)\end{array}$ & $\begin{array}{l}0.0175 * * * \\
(0.00629)\end{array}$ & $\begin{array}{l}0.0194 * * * \\
(0.00682)\end{array}$ & $\begin{array}{c}0.0116 \\
(0.0124)\end{array}$ \\
\hline Foreign-owned & $\begin{array}{l}-0.00714 \\
(0.00674)\end{array}$ & $\begin{array}{l}-0.0249 \\
(0.0190)\end{array}$ & $\begin{array}{l}-0.0357 * * \\
(0.0144)\end{array}$ & $\begin{array}{l}-0.0545^{* *} \\
(0.0270)\end{array}$ \\
\hline Age & $\begin{array}{l}-0.000133 \\
(0.000282)\end{array}$ & $\begin{array}{l}-0.000621 \\
(0.000816)\end{array}$ & $\begin{array}{l}-4.91 \mathrm{e}-05 \\
(0.000701)\end{array}$ & $\begin{array}{r}0.000109 \\
(0.00119)\end{array}$ \\
\hline Age squared & $\begin{array}{c}9.31 \mathrm{e}-07 \\
(2.37 \mathrm{e}-06)\end{array}$ & $\begin{array}{l}4.29 \mathrm{e}-06 \\
(6.38 \mathrm{e}-06)\end{array}$ & $\begin{array}{l}4.08 \mathrm{e}-06 \\
(7.02 \mathrm{e}-06)\end{array}$ & $\begin{array}{c}5.32 \mathrm{e}-06 \\
(1.16 \mathrm{e}-05)\end{array}$ \\
\hline Patents obtained & $\begin{array}{c}0.0243 \\
(0.0338)\end{array}$ & $\begin{array}{l}0.0204 \\
(0.0515)\end{array}$ & $\begin{array}{l}-0.00501 \\
(0.0365)\end{array}$ & $\begin{array}{l}-0.0408 \\
(0.0408)\end{array}$ \\
\hline $\mathrm{K} / \mathrm{L}(\mathrm{t}-1)$ & $\begin{array}{l}3.34 \mathrm{e}-05 \\
(0.000974)\end{array}$ & $\begin{array}{r}2.85 \mathrm{e}-05 \\
(0.00262)\end{array}$ & $\begin{array}{l}-0.00756 \\
(0.00873)\end{array}$ & $\begin{array}{l}-0.00822 \\
(0.0138)\end{array}$ \\
\hline Productivity(t - 1) & $\begin{array}{c}0.00326 \\
(0.00313)\end{array}$ & $\begin{array}{c}0.00427 \\
(0.00862)\end{array}$ & $\begin{array}{c}0.00385 \\
(0.00897)\end{array}$ & $\begin{array}{l}-0.0158 \\
(0.0172)\end{array}$ \\
\hline Network & $\begin{array}{c}0.00576 \\
(0.00732)\end{array}$ & $\begin{array}{l}-0.00558 \\
(0.0168)\end{array}$ & $\begin{array}{c}0.0298 \\
(0.0253)\end{array}$ & $\begin{array}{c}0.0209 \\
(0.0335)\end{array}$ \\
\hline Group & $\begin{array}{l}-0.00492 \\
(0.00631)\end{array}$ & $\begin{array}{l}-0.0150 \\
(0.0185)\end{array}$ & $\begin{array}{c}0.0110 \\
(0.0222)\end{array}$ & $\begin{array}{c}0.0209 \\
(0.0372)\end{array}$ \\
\hline Outlets & $\begin{array}{l}-7.17 \mathrm{e}-05 \\
(0.000121)\end{array}$ & $\begin{array}{l}-0.000261 \\
(0.000425)\end{array}$ & $\begin{array}{l}-0.00238 \\
(0.00339)\end{array}$ & $\begin{array}{l}-0.00335 \\
(0.00563)\end{array}$ \\
\hline Montevideo & $\begin{array}{c}0.00954^{*} \\
(0.00557)\end{array}$ & $\begin{array}{c}0.0267 \\
(0.0167)\end{array}$ & $\begin{array}{c}0.00308 \\
(0.0176)\end{array}$ & $\begin{array}{c}0.00826 \\
(0.0291)\end{array}$ \\
\hline Industry dummies & Yes & Yes & Yes & Yes \\
\hline Observations & 1758 & 684 & 1156 & 698 \\
\hline Log likelihood & -167.1 & -135.1 & -255.6 & -218.9 \\
\hline
\end{tabular}

Source: prepared by the authors on the basis of Innovation Surveys (2004-2006 and 2007-2009) and Economic Activity Surveys conducted in Uruguay.

Note: $\mathrm{IE}=$ innovation expenditure. Standard errors in parentheses. $* * * \mathrm{p}<0.01 ; * * \mathrm{p}<0.05 ; * \mathrm{p}<0.1$. 
Tables A.5 and A.6 and figures A.1 and A. 2 in the annex report the balance test results for the covariates in the treatment and control groups and the estimated propensity score (to check for common support). The results are satisfactory, showing that, after matching, the hypothesis that the mean of the covariates in the control and treatment groups is equal in the sample cannot be rejected. Also, the conclusion from analysis of the estimated propensity scores is that there is significant overlap.

Table 9 shows the effects of financial support on the financially supported firms in the service and manufacturing sectors. The results show that financial support stimulated both private and total investment in the manufacturing sector. Financially supported firms invested $2 \%$ more of their sales in innovation than nonsupported firms. This result indicates that not only does no crowding-out effect exist, but that financial support increases private innovation investment. In the service sector, conversely, the mean of private innovation effort is positive but not significantly different from zero, while total investment is higher for treated firms. This also signals that there is no crowding-out effect and that instead firms add the amount of the support to their private investment. This led us to conclude that there was no crowding-out effect in either sector and that for the manufacturing sector there was evidence of a positive effect on private investment.

R\&D investment as a proportion of innovation expenditures was higher at treated firms, in both the service and manufacturing sectors. Innovative sales were higher at financially supported firms than at control firms in both sectors. Innovative sales were $20 \%$ higher than for control firms in the service sector, compared with $9 \%$ in the manufacturing sector. Productivity was higher at financially supported firms in the service sector, while in the manufacturing sector this effect was negative, though not statistically significant. The first result was unexpected given the short time frame of the evaluation. ${ }^{3}$ Finally, there were no significant effects on patent applications.

When the sample is restricted to firms with positive innovation expenditures (table 10), the mean difference in private effort between the treated and control groups was not statistically significant in either sector. This means that public financial support had no crowdingout effect. Also, there was no stimulating effect on total innovation expenditures, $R \& D$ expenditures as a proportion of innovation expenditures, patent applications or private effort. Further, the effects on innovative sales and productivity were not significant.

To summarize, when the differential impact of financial support in the service and manufacturing sectors was analysed, the results led us to conclude that public funds did not crowd out private funds in either sector, but that there were no effects on firms that would have carried out innovation activities in any case.

3 The recent literature has suggested alternative hypotheses for the failure of innovation policy to affect productivity. See the introduction for some of these. We are grateful to an anonymous referee for pointing this out.

TABLE 9

The effects of financial support on supported firms

\begin{tabular}{|c|c|c|c|c|c|c|}
\hline & (1) & (2) & (3) & (4) & $(5)$ & (6) \\
\hline Dependent variable & $\begin{array}{l}\text { Innovation } \\
\text { expenditure } \\
\text { effort }\end{array}$ & Private effort & $\mathrm{R} \& \mathrm{D}^{\mathrm{a}}$ & $\begin{array}{l}\text { Innovative } \\
\text { sales }^{b}\end{array}$ & $\begin{array}{c}\text { Patent } \\
\text { applications }\end{array}$ & Productivity \\
\hline Service sector & $\begin{array}{l}4.370 * * \\
(1.815)\end{array}$ & $\begin{array}{l}1.490 \\
(1.223)\end{array}$ & $\begin{array}{c}8.753 * \\
(4.969)\end{array}$ & $\begin{array}{l}20.73 * * * \\
(7.287)\end{array}$ & $\begin{array}{c}0.0632 \\
(0.0487)\end{array}$ & $\begin{array}{l}0.366^{* * *} \\
(0.178)\end{array}$ \\
\hline Treated group & 38 & 38 & 38 & 38 & 38 & 38 \\
\hline Off support & 1 & 1 & 1 & 1 & 1 & 1 \\
\hline Potential control group & 1758 & 1758 & 1776 & 1775 & 1777 & 1778 \\
\hline Manufacturing sector & $\begin{array}{l}4.402 * * \\
(1.999)\end{array}$ & $\begin{array}{l}1.951 * \\
(1.159)\end{array}$ & $\begin{array}{l}\text { 6.704** } \\
(3.303)\end{array}$ & $\begin{array}{c}9.924 * \\
(5.240)\end{array}$ & $\begin{array}{l}-0.0139 \\
(0.0224)\end{array}$ & $\begin{array}{l}-0.0102 \\
(0.110)\end{array}$ \\
\hline Treated group & 72 & 72 & 72 & 72 & 72 & 72 \\
\hline Off support & 0 & 0 & 0 & 0 & 0 & 0 \\
\hline Potential control group & 1156 & 1156 & 1157 & 1156 & 1158 & 1159 \\
\hline
\end{tabular}

Source: prepared by the authors on the basis of Innovation Surveys (2004-2006 and 2007-2009) and Economic Activity Surveys conducted in Uruguay.

a Share of innovation expenditure that is R\&D.

b Share of sales due to innovation.

Note: bootstrapped standard errors in parentheses. 100 replications. $* * * \mathrm{p}<0.01 ; * * \mathrm{p}<0.05 ; * \mathrm{p}<0.1$. 
TABLE 10

The effects of financial support on supported firms with positive innovation expenditures

\begin{tabular}{|c|c|c|c|c|c|c|}
\hline & (1) & (2) & (3) & (4) & (5) & (6) \\
\hline & $\begin{array}{c}\text { Innovation } \\
\text { expenditure } \\
\text { effort }\end{array}$ & Private effort & $\mathrm{R} \& \mathrm{D}^{\mathrm{a}}$ & $\begin{array}{c}\text { Innovative } \\
\text { sales }^{\mathrm{b}}\end{array}$ & $\begin{array}{c}\text { Patent } \\
\text { applications }\end{array}$ & Productivity \\
\hline Service sector & $\begin{array}{c}2.866 \\
(1.908)\end{array}$ & $\begin{array}{l}-0.0910 \\
(1.227)\end{array}$ & $\begin{array}{c}4.364 \\
(5.793)\end{array}$ & $\begin{array}{c}6.341 \\
(8.986)\end{array}$ & $\begin{array}{c}0.0288 \\
(0.0615)\end{array}$ & $\begin{array}{c}0.230 \\
(0.174)\end{array}$ \\
\hline Treated group & 38 & 38 & 38 & 38 & 38 & 38 \\
\hline Off support & 0 & 0 & 0 & 0 & 0 & 0 \\
\hline Potential control group & 684 & 684 & 684 & 684 & 684 & 684 \\
\hline Manufacturing sector & $\begin{array}{c}3.005 \\
(1.899)\end{array}$ & $\begin{array}{c}0.501 \\
(1.287)\end{array}$ & $\begin{array}{c}3.912 \\
(3.662)\end{array}$ & $\begin{array}{c}4.585 \\
(4.955)\end{array}$ & $\begin{array}{l}-0.0435 \\
(0.0333)\end{array}$ & $\begin{array}{l}0.00676 \\
(0.125)\end{array}$ \\
\hline Treated group & 69 & 69 & 69 & 69 & 69 & 69 \\
\hline Off support & 2 & 2 & 2 & 2 & 2 & 2 \\
\hline Potential control group & 698 & 698 & 698 & 698 & 698 & 698 \\
\hline
\end{tabular}

Source: prepared by the authors on the basis of Innovation Surveys (2004-2006 and 2007-2009) and Economic Activity Surveys conducted in Uruguay.

a Share of innovation expenditure that is $R \& D$.

b Share of sales due to innovation.

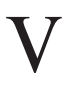

\section{Conclusion}

This paper evaluates the impact of public financial support to innovation using quasi-experimental methods and Innovation Survey data from Uruguay for the manufacturing and service sectors. It contributes to the literature in three ways. First, it presents an evaluation of the impact of public financial support to innovation on innovation expenditures. The analysis is therefore extended beyond the R\&D context. Second, it analyses the possible heterogeneity of effects on services and manufacturing. Finally, the evaluation is for a developing Latin American country where the empirical evidence is scarce.

On the basis of the results, we conclude that public funds do not crowd out private funds and that public financing in Uruguay seems to induce some increase in private innovation effort. Moreover, financial support induces some increase in $\mathrm{R} \& \mathrm{D}$ expenditures as a proportion of innovation expenditures and in innovative sales. However, public funds do not significantly stimulate private expenditures by firms that would have carried out innovation activities in the absence of financial support.

From analysing the differential impact of financial support in the service and manufacturing sectors, we conclude that public funds are not crowding out private funds in either sector, but that there is a crowding-in effect at manufacturing firms. The positive impact of public funding on R\&D and innovative sales is larger in the service sector than in manufacturing. An unexpected (given the short time frame of the evaluation) positive effect of public funding on productivity was found for service firms.

When the control group was restricted to firms that innovated, the above-mentioned positive effects vanished. This implies that the positive impact is probably an inducement effect (i.e. firms are induced to innovate thanks to the public funding).

These results call for a rethink of public innovation policy. There is evidence that public financial support is biased towards manufacturing firms, but the results show that the positive effects could be even bigger for service firms. This finding raises the question of how public funds are and should be targeted on the service sector.

Finally, more research is needed on the relative effectiveness of different innovation support instruments. Such research could help with the effort to target instruments wherever they would have the biggest impact. 


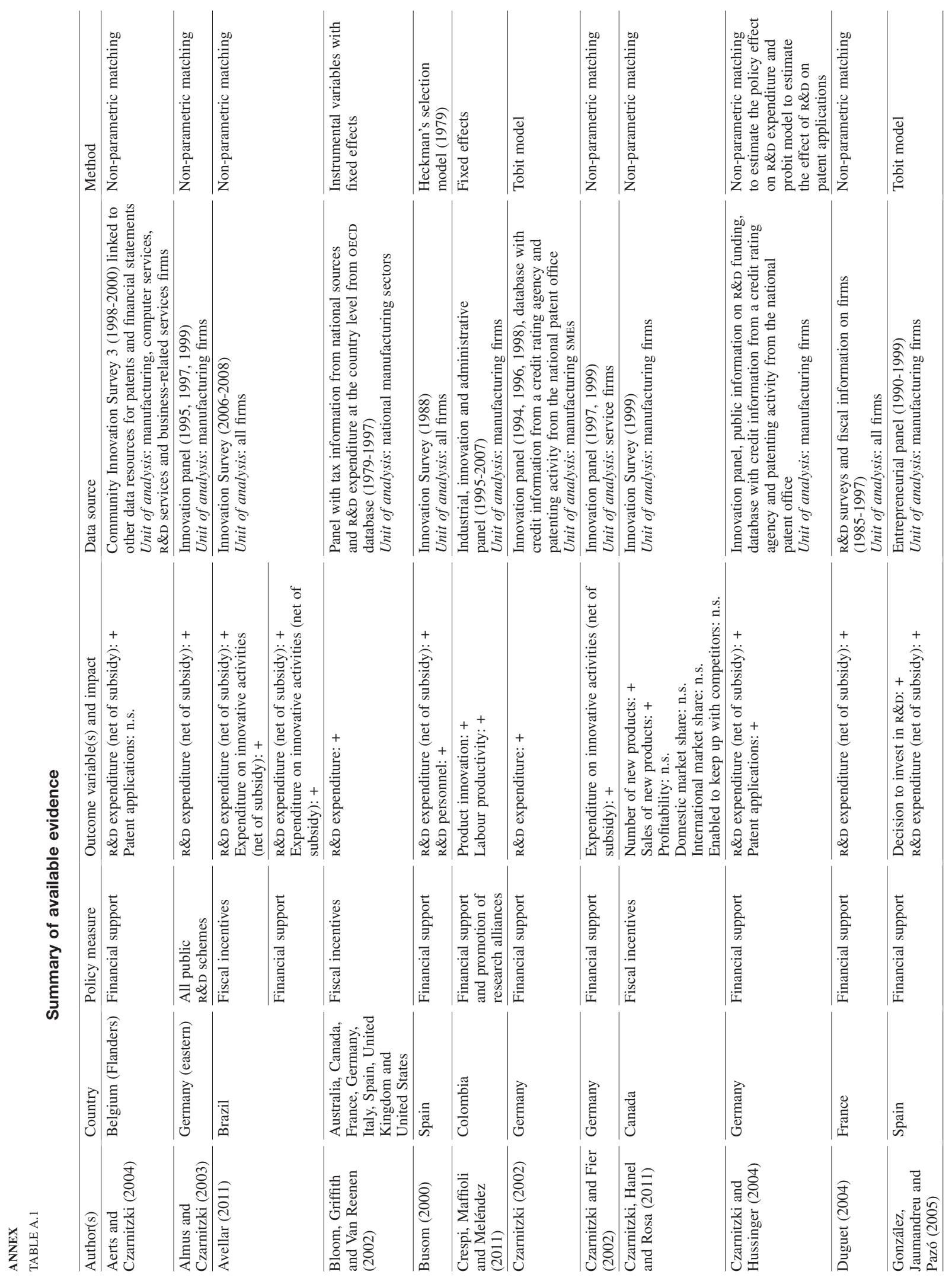




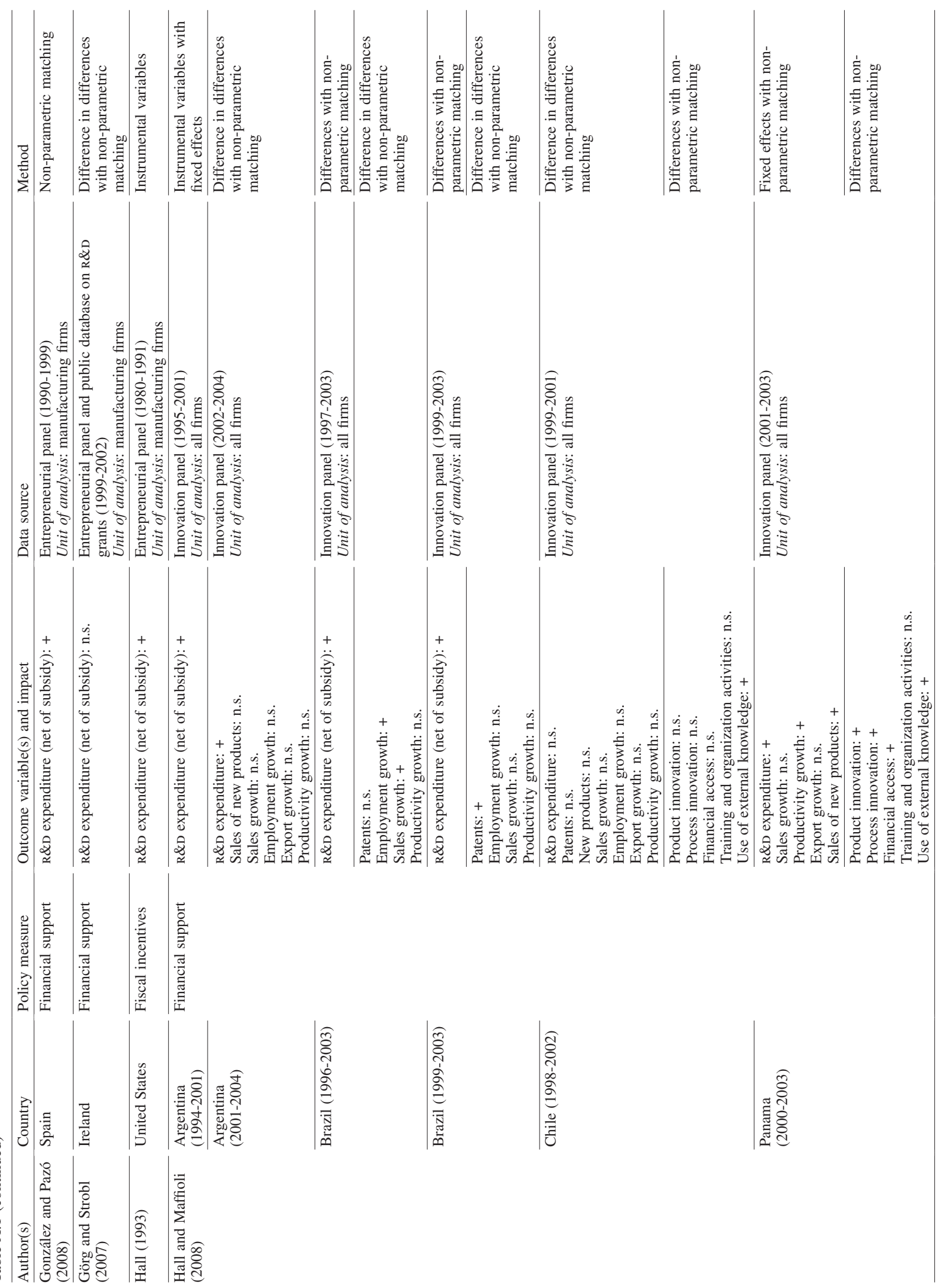



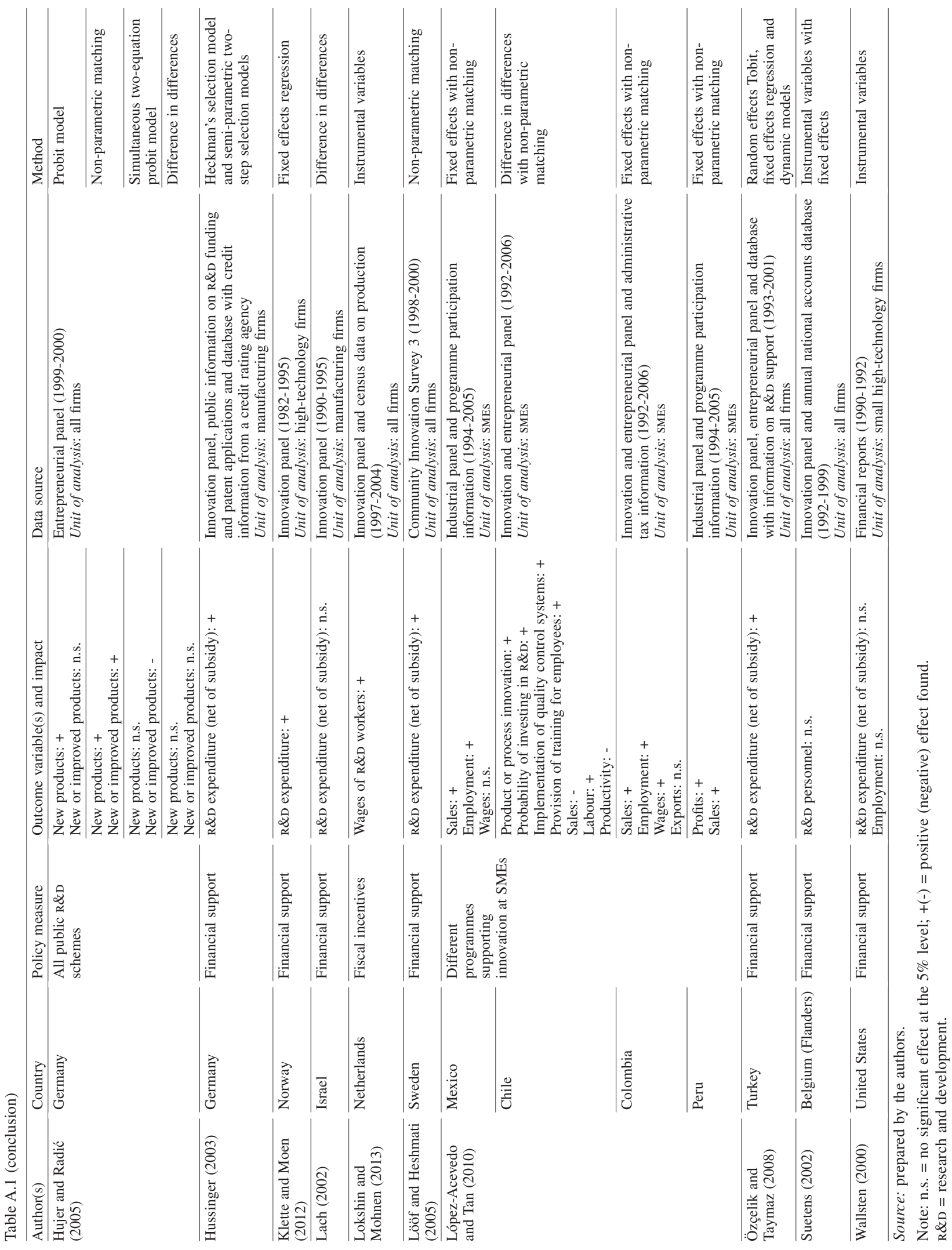


\section{Some innovation support programmes in use in Uruguay as of end-2011}

\begin{tabular}{|c|c|c|c|c|c|c|}
\hline & \multicolumn{2}{|c|}{$\begin{array}{l}\text { Wide-coverage } \\
\text { innovation projects }\end{array}$} & \multirow{2}{*}{$\begin{array}{l}\text { High-impact } \\
\text { innovation projects }\end{array}$} & \multirow{2}{*}{$\begin{array}{l}\text { Prototypes with } \\
\text { innovative potential }\end{array}$} & \multirow{2}{*}{$\begin{array}{l}\text { Certification and new } \\
\text { markets for exports }\end{array}$} & \multirow{2}{*}{$\begin{array}{l}\text { Improved management } \\
\text { and certification }\end{array}$} \\
\hline & $\begin{array}{l}\text { Small } \\
(\text { SMEs })\end{array}$ & Large & & & & \\
\hline Objective & \multicolumn{2}{|c|}{$\begin{array}{l}\text { Promote business } \\
\text { innovation to } \\
\text { improve the } \\
\text { competitiveness, } \\
\text { productivity and } \\
\text { profitability of } \\
\text { enterprises. }\end{array}$} & $\begin{array}{l}\text { Promote } \\
\text { high-impact } \\
\text { innovations. }\end{array}$ & \multicolumn{3}{|c|}{$\begin{array}{l}\text { Promote business innovation in order to improve competitiveness, } \\
\text { productivity and profitability. }\end{array}$} \\
\hline Type & \multicolumn{2}{|c|}{$\begin{array}{l}\text { Subsidy to } \\
\text { innovation projects. }\end{array}$} & $\begin{array}{l}\text { Subsidy to } \\
\text { projects with } \\
\text { high economic, } \\
\text { environmental and } \\
\text { social impact. }\end{array}$ & $\begin{array}{l}\text { Subsidy and support } \\
\text { to companies in } \\
\text { the process of } \\
\text { converting new ideas } \\
\text { into prototypes or } \\
\text { creating spin-offs. }\end{array}$ & $\begin{array}{l}\text { Subsidy to certification } \\
\text { projects that show direct } \\
\text { impact on the opening } \\
\text { of new export markets } \\
\text { or the maintenance } \\
\text { of markets that are } \\
\text { important to } \\
\text { the company. }\end{array}$ & $\begin{array}{l}\text { Subsidy for improving } \\
\text { or implementing quality } \\
\text { certifiable management } \\
\text { systems to international } \\
\text { standards, technical } \\
\text { standards or process and } \\
\text { product certification. }\end{array}$ \\
\hline
\end{tabular}

Rate of subsidy

$60 \%$

$70 \%$

Rate of extra subsidy $5 \%$ if the project is presented with an R\&D institution in a relevant association

\begin{tabular}{lrrrrrr}
\hline Maximum (dollars) & 24000 & 250000 & 400000 & 70000 & 50000 & 12000 \\
\hline Duration (months) & 24 & 36 & 36 & 24 & 12 & 24 \\
\hline
\end{tabular}

Source: National Research and Innovation Agency (ANII), "Resultados de instrumentos de apoyo a la innovación empresarial", Documento de Trabajo, No. 5, Montevideo, 2012.

TABLE A.3

The effects of financial support in a sample without imputed observations

\begin{tabular}{|c|c|c|c|c|c|c|}
\hline & (1) & (2) & (3) & (4) & (5) & (6) \\
\hline Dependent variable & $\begin{array}{c}\text { Innovation } \\
\text { expenditure effort }\end{array}$ & Private effort & Innovative sales $^{\mathrm{a}}$ & $\mathrm{R} \& \mathrm{D}^{\mathrm{b}}$ & $\begin{array}{c}\text { Patent } \\
\text { applications }\end{array}$ & Productivity \\
\hline ATT & $\begin{array}{l}4.534 * * * \\
(1.489)\end{array}$ & $\begin{array}{l}2.134 * * \\
(1.027)\end{array}$ & $\begin{array}{l}15.23 * * * \\
(4.672)\end{array}$ & $\begin{array}{l}5.032 * \\
(3.015)\end{array}$ & $\begin{array}{c}0.0154 \\
(0.0312)\end{array}$ & $\begin{array}{l}-0.0263 \\
(0.130)\end{array}$ \\
\hline Treated group & 78 & 78 & 78 & 78 & 78 & 78 \\
\hline Off support & 2 & 2 & 2 & 2 & 2 & 2 \\
\hline Potential control group & 1861 & 1861 & 1861 & 1861 & 1861 & 1861 \\
\hline
\end{tabular}

Source: prepared by the authors on the basis of Innovation Surveys (2004-2006 and 2007-2009) and Economic Activity Surveys conducted in Uruguay.

a Share of sales due to innovation.

b Share of innovation expenditure that is R\&D.

Note: bootstrapped standard errors in parentheses. 100 replications $* * * \mathrm{p}<0.01, * * \mathrm{p}<0.05, * \mathrm{p}<0.1$.

$\mathrm{R} \& \mathrm{D}=$ research and development.

The effects of financial support in a sample without imputed observations and with positive innovation expenditure

\begin{tabular}{|c|c|c|c|c|c|c|}
\hline & $(1)$ & (2) & (3) & (4) & (5) & (6) \\
\hline & $\begin{array}{c}\text { Innovation } \\
\text { expenditure effort }\end{array}$ & Private effort & Innovative sales $^{\mathrm{a}}$ & $\mathrm{R} \& \mathrm{D}^{\mathrm{b}}$ & $\begin{array}{c}\text { Patent } \\
\text { applications }\end{array}$ & Productivity \\
\hline \multirow[t]{2}{*}{ ATT } & $3.335 * *$ & 0.903 & 6.690 & 2.511 & 0.00281 & -0.0981 \\
\hline & $(1.508)$ & $(1.111)$ & $(5.721)$ & $(3.516)$ & $(0.0357)$ & $(0.119)$ \\
\hline Treated group & 77 & 77 & 77 & 77 & 77 & 77 \\
\hline Off support & 2 & 2 & 2 & 2 & 2 & 2 \\
\hline Potential control group & 918 & 918 & 918 & 918 & 918 & 918 \\
\hline
\end{tabular}

Source: prepared by the authors on the basis of Innovation Surveys (2004-2006 and 2007-2009) and Economic Activity Surveys conducted in Uruguay.

a Share of sales due to innovation.

b Share of innovation expenditure that is R\&D.

Note: bootstrapped standard errors in parentheses. 100 replications $* * \mathrm{p}<0.05$.

$\mathrm{R} \& \mathrm{D}=$ research and development. 
TABLE A.5

Service sector: mean comparison of supported firms and non-supported firms on selected controls

\begin{tabular}{|c|c|c|c|c|c|c|c|c|c|c|c|c|c|}
\hline \multirow[b]{2}{*}{ Variable } & \multirow[b]{2}{*}{ Matching } & \multicolumn{4}{|c|}{ Mean } & \multicolumn{2}{|c|}{ t-test } & \multicolumn{4}{|c|}{ Mean } & \multicolumn{2}{|c|}{ t-test } \\
\hline & & Treated & Control & $\%$ bias & $\begin{array}{l}\% \text { reduct } \\
\text { bias }\end{array}$ & $\mathrm{t}$ & $\mathrm{p}>\mathrm{t}$ & Treated & Control & $\%$ bias & $\begin{array}{l}\% \text { reduct } \\
\text { bias }\end{array}$ & $\mathrm{t}$ & $\mathrm{p}>\mathrm{t}$ \\
\hline \multirow[t]{2}{*}{ Size } & Unmatched & 4.69 & 3.70 & 63.7 & & 4.4 & 0 & 4.74 & 4.18 & 35.3 & & 2.30 & 0.02 \\
\hline & Matched & 4.57 & 4.44 & 8.5 & 86.6 & 0.38 & 0.704 & 4.62 & 4.48 & 8.7 & 75.2 & 0.39 & 0.70 \\
\hline \multirow[t]{2}{*}{ Foreign-owned } & Unmatched & 0.08 & 0.09 & -6.2 & & -0.37 & 0.714 & 0.08 & 0.15 & -21.1 & & -1.14 & 0.33 \\
\hline & Matched & 0.08 & 0.10 & -9 & -46.9 & -0.38 & 0.708 & 0.08 & 0.16 & -23.8 & -12.7 & -0.98 & 0.35 \\
\hline \multirow[t]{2}{*}{ Age } & Unmatched & 23.90 & 18.25 & 24.9 & & 1.89 & 0.058 & 23.95 & 20.64 & 13.8 & & 0.94 & 0.51 \\
\hline & Matched & 24.34 & 18.75 & 24.7 & 1.1 & 1.02 & 0.31 & 24.41 & 20.64 & 15.7 & -13.7 & 0.66 & 0.38 \\
\hline \multirow[t]{2}{*}{ Patents obtained } & Unmatched & 0.05 & 0.01 & 22.6 & & 2.2 & 0.028 & 0.05 & 0.03 & 12.5 & & 0.88 & 0.97 \\
\hline & Matched & 0.05 & 0.03 & 11.2 & 50.4 & 0.41 & 0.681 & 0.05 & 0.05 & 1 & 91.8 & 0.04 & 0.97 \\
\hline \multirow[t]{2}{*}{$\mathrm{K} / \mathrm{L}$} & Unmatched & 0.84 & 0.65 & 11.7 & & 0.58 & 0.565 & 0.86 & 0.74 & 5.2 & & 0.24 & 0.81 \\
\hline & Matched & 0.86 & 0.79 & 4.1 & 64.5 & 0.18 & 0.861 & 0.88 & 0.63 & 10.9 & -110.7 & 0.98 & 0.33 \\
\hline \multirow[t]{2}{*}{ Productivity $(\mathrm{t}-1)$} & Unmatched & 13.39 & 13.10 & 25.5 & & 1.73 & 0.084 & 13.40 & 13.31 & 8.2 & & 0.53 & 0.60 \\
\hline & Matched & 13.41 & 13.29 & 10.4 & 59.3 & 0.44 & 0.665 & 13.42 & 13.42 & -0.4 & 94.7 & -0.02 & 0.99 \\
\hline Network & Matched & 0.29 & 0.21 & 18.8 & 2.9 & 0.8 & 0.429 & 0.27 & 0.25 & 4.8 & 46 & 0.21 & 0.84 \\
\hline \multirow[t]{2}{*}{ Group } & Unmatched & 0.15 & 0.14 & 3.3 & & 0.21 & 0.833 & 0.16 & 0.20 & -12 & & -0.69 & 0.49 \\
\hline & Matched & 0.16 & 0.13 & 8.8 & -164.8 & 0.38 & 0.702 & 0.16 & 0.20 & -8.9 & 26 & -0.37 & 0.70 \\
\hline \multirow[t]{2}{*}{ Outlets } & Unmatched & 4.79 & 3.39 & 5.7 & & 0.27 & 0.791 & 4.89 & 6.07 & -3 & & -0.14 & 0.89 \\
\hline & Matched & 4.89 & 2.95 & 7.9 & -39.2 & 0.95 & 0.344 & 5.00 & 3.22 & 4.6 & -51.1 & 0.83 & 0.41 \\
\hline \multirow[t]{2}{*}{ In Montevideo } & Unmatched & 0.8718 & 0.7353 & 34.7 & & 1.92 & 0.055 & 0.8947 & 0.7988 & 26.7 & & 1.45 & 0.15 \\
\hline & Matched & 0.8684 & 0.8022 & 16.8 & 51.5 & 0.76 & 0.447 & 0.8919 & 0.8382 & 15 & 44 & 0.66 & 0.51 \\
\hline
\end{tabular}

Source: prepared by the authors on the basis of Innovation Surveys (2004-2006 and 2007-2009) and Economic Activity Surveys conducted in Uruguay.

TABLE A.6

Manufacturing sector: mean comparison of supported firms and non-supported firms on selected controls

\begin{tabular}{|c|c|c|c|c|c|c|c|c|c|c|c|c|}
\hline \multirow[b]{2}{*}{ Variable } & \multirow[b]{2}{*}{ Matching } & \multicolumn{4}{|c|}{ Mean } & \multicolumn{2}{|c|}{ t-test } & \multicolumn{4}{|c|}{ Mean } & \multirow{2}{*}{$\begin{array}{l}\mathrm{t} \text {-test } \\
\mathrm{p}>\mathrm{t}\end{array}$} \\
\hline & & Treated & Control & $\begin{array}{c}\% \\
\text { bias }\end{array}$ & $\begin{array}{l}\% \text { reduct } \\
\text { bias }\end{array}$ & $\mathrm{t}$ & $\mathrm{p}>\mathrm{t}$ & Treated & Control & $\%$ bias & $\begin{array}{l}\% \text { reduct } \\
\text { bias }\end{array}$ & \\
\hline \multirow[t]{2}{*}{ Size } & Unmatched & 4.22 & 3.81 & 36.6 & & 2.83 & 0.006 & 4.22 & 4.12 & 8.9 & & 0.69 \\
\hline & Matched & 4.22 & 4.21 & 1.3 & 96.5 & 0.08 & 0.773 & 4.26 & 4.29 & -2.9 & 67.6 & -0.18 \\
\hline \multirow[t]{2}{*}{ Foreign-owned } & Unmatched & 0.10 & 0.13 & -9.8 & & -0.77 & 0.651 & 0.10 & 0.18 & -22.4 & & -1.64 \\
\hline & Matched & 0.10 & 0.17 & -21.5 & -119.3 & -1.2 & 0.841 & 0.10 & 0.19 & -25.9 & -15.6 & -1.45 \\
\hline \multirow[t]{2}{*}{ Age } & Unmatched & 32.29 & 27.48 & 21.8 & & 1.9 & 0.973 & 31.93 & 29.09 & 12.5 & & 1.03 \\
\hline & Matched & 32.29 & 28.01 & 19.4 & 11.1 & 1.19 & 0.635 & 32.57 & 28.84 & 16.4 & -31.2 & 0.97 \\
\hline \multirow[t]{2}{*}{ Patents obtained } & Unmatched & 0.03 & 0.03 & 0.6 & & 0.05 & 0.008 & 0.03 & 0.04 & -8.8 & & -0.65 \\
\hline & Matched & 0.03 & 0.04 & -7.8 & -1149 & -0.42 & 0.721 & 0.03 & 0.05 & -12.1 & -37.2 & -0.66 \\
\hline \multirow[t]{2}{*}{$\mathrm{K} / \mathrm{L}$} & Unmatched & 0.52 & 0.59 & -6.7 & & -0.43 & 0.401 & 0.53 & 0.72 & -17.7 & & -1.13 \\
\hline & Matched & 0.52 & 0.66 & -12.9 & -94.3 & -0.81 & 0.422 & 0.54 & 0.73 & -17.6 & 0.5 & -0.95 \\
\hline \multirow[t]{2}{*}{ Productivity $(\mathrm{t}-1)$} & Unmatched & 13.93 & 13.78 & 16.2 & & 1.2 & 0.444 & 13.92 & 14.05 & -15.3 & & -1.15 \\
\hline & Matched & 13.93 & 13.90 & 2.5 & 84.6 & 0.15 & 0.787 & 13.94 & 14.05 & -12.4 & 19.1 & -0.70 \\
\hline Network & Matched & 0.17 & 0.12 & 14.1 & 28.7 & 0.81 & 0.964 & 0.17 & 0.16 & 4.3 & 37.8 & 0.24 \\
\hline \multirow[t]{2}{*}{ Group } & Unmatched & 0.18 & 0.15 & 6.8 & & 0.58 & 0.058 & 0.17 & 0.19 & -6.6 & & -0.52 \\
\hline & Matched & 0.18 & 0.17 & 1.8 & 74 & 0.1 & 0.684 & 0.17 & 0.20 & -5.9 & 10.6 & -0.33 \\
\hline \multirow[t]{2}{*}{ Outlets } & Unmatched & 1.85 & 1.81 & 1.9 & & 0.12 & 0.958 & 1.86 & 1.83 & 1.7 & & 0.11 \\
\hline & Matched & 1.85 & 1.76 & 4.3 & -130 & 0.25 & 0.654 & 1.87 & 1.61 & 13.7 & -717.3 & 1.14 \\
\hline \multirow[t]{2}{*}{ In Montevideo } & & 0.8333 & 0.7915 & 10.7 & & 0.85 & & 0.831 & 0.7927 & 9.8 & & 0.76 \\
\hline & & 0.8333 & 0.7913 & 10.7 & -0.5 & 0.64 & & 0.8261 & 0.8 & 6.7 & 31.9 & 0.38 \\
\hline
\end{tabular}

Source: prepared by the authors on the basis of Innovation Surveys (2004-2006 and 2007-2009) and Economic Activity Surveys conducted in Uruguay. 
Service sector: propensity scores of treated and potential controls for all firms (left panel) and observations with positive innovation expenditure only (right panel)
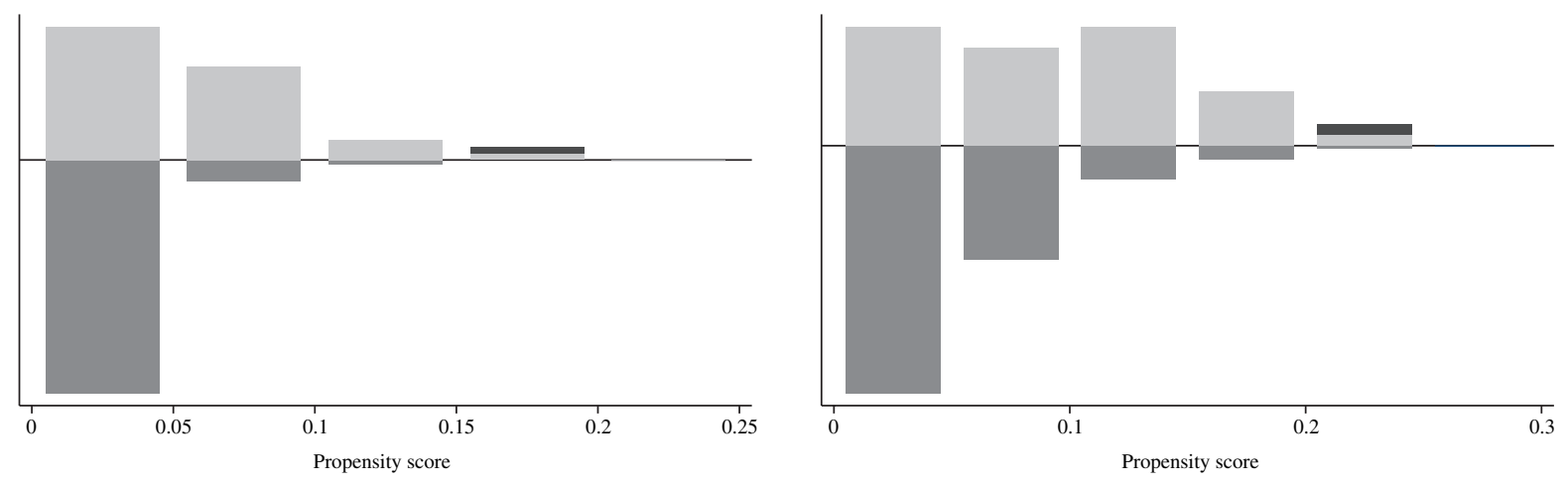

Untreated

Treated: on support

Treated: off support

Source: prepared by the authors on the basis of Innovation Surveys (2004-2006 and 2007-2009) and Economic Activity Surveys conducted in Uruguay.

FIGURE A.2

Manufacturing sector: propensity scores of treated and potential controls for all firms (left panel) and observations with positive innovation expenditure only (right panel)
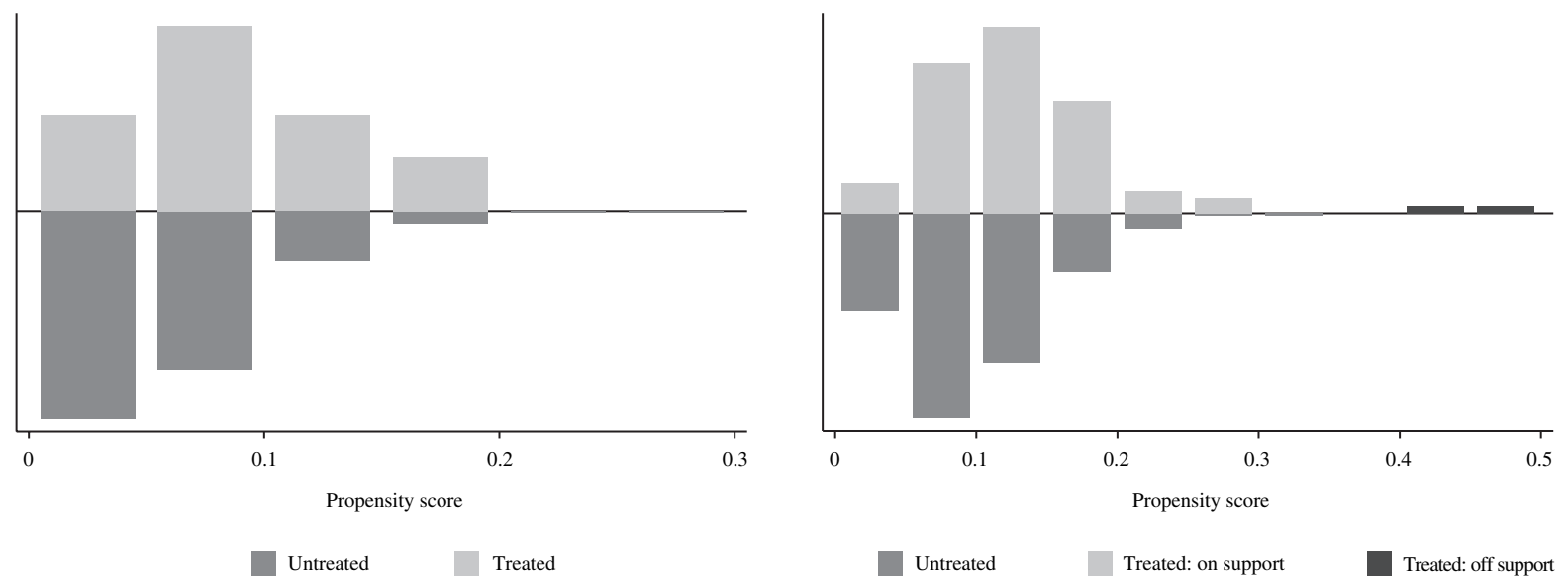

Source: prepared by the authors on the basis of Innovation Surveys (2004-2006 and 2007-2009) and Economic Activity Surveys conducted in Uruguay. 


\section{Bibliography}

Aerts, K. and D. Czarnitzki (2004), "Using innovation survey data to evaluate R\&D policy: the case of Belgium", Discussion Paper, No. 04-055, Mannheim, Centre for Economic European Research (ZEW).

Almus, M. and D. Czarnitzki (2003), "The effects of public R\&D subsidies on firms' innovation activities: the case of Eastern Germany", Journal of Business and Economic Statistics, vol. 21, No. 2, American Statistical Association.

Andrews, D. and C. Criscuolo (2013), "Knowledge based capital, innovation and resource allocation", $O E C D$ Economics Department Working Papers, No. 1046, Paris, OECD Publishing.

ANII (Innovation and Research National Agency) (2012), "Resultados de instrumentos de apoyo a la innovación empresarial", Documento de Trabajo, No. 5, Montevideo.

Avellar, A.P. (2011), "Evaluating the Impacts of Innovation Policy: Evidences from Brazil", unpublished.

Avellar, A.P. and P.F. Alves (2008), "Avaliação de impacto de programas de incentivos fiscais a inovação: um estudo sobre os efeitos do PDTI no Brasil", Economia, vol. 9, No. 1, National Association of Centers for Post-graduation in Economics.

Bloom, N., R. Griffith and J. Van Reenen (2002), "Do R\&D tax credits work? Evidence from a panel of countries 1979-1997', Journal of Public Economics, vol. 85, No. 1, Amsterdam, Elsevier.

Busom, I. (2000), "An empirical evaluation of the effects of R\&D subsidies", Economics of Innovation and New Technology, vol. 9, No. 2, Taylor \& Francis.

Caliendo, M. and S. Kopeinig (2008), "Some practical guidance for the implementation of propensity score matching", Journal of Economic Surveys, vol. 22, No. 1, Wiley.

CIS (Community Innovation Survey) [online] http://ec.europa.eu/ eurostat/web/microdata/community_innovation_survey.

Crespi, G., A. Maffioli and M. Meléndez (2011), "Public support to innovation: the Colombian COLCIENCIAS' experience", Technical Notes, No. IDB-TN-264, Washington, D.C., InterAmerican Development Bank.

Crespi, G. and others (2011), "Evaluating the impact of science, technology and innovation programs: a methodological toolkit", Technical Notes, No. IDB-TN-333, Washington, D.C., InterAmerican Development Bank.

Czarnitzki, D. (2002), "Research and development: financial constraints and the role of public funding for small and medium-sized enterprises", ZEW Discussion Paper, No. 02-74, Mannheim, Centre for Economic European Research (ZEW).

Czarnitzki, D. and A. Fier (2002), "Do innovation subsidies crowd out private investment? Evidence from the German service sector", ZEW Discussion Paper, No. 02-04, Mannheim, Centre for Economic European Research (ZEW).

Czarnitzki, D., P. Hanel and J.M. Rosa (2011), "Evaluating the impact of R\&D tax credits on innovation: a microeconometric study on Canadian firms", Research Policy, vol. 40, No. 2, Amsterdam, Elsevier.

Czarnitzki, D. and K. Hussinger (2004), "The link between R\&D subsidies, R\&D spending and technological performance", ZEW Discussion Paper, No. 04-056, Mannheim, Centre for Economic European Research (ZEW).

David, P., B.H. Hall and A.A. Toole (2000), "Is public R\&D a complement or substitute for private R\&D? A review of the econometric evidence", Research Policy, vol. 29, No. 4-5, Amsterdam, Elsevier.
Duguet, E. (2004), "Are R\&D subsidies a substitute or a complement to privately funded R\&D? Evidence from France using propensity score methods for non-experimental data", Revue d'Économie Politique, vol. 114, No. 2, Dalloz.

González, X., J. Jaumandreu and C. Pazó (2005), "Barriers to innovation and subsidy effectiveness", RAND Journal of Economics, vol. 36, No. 4, The RAND Corporation.

González, X. and C. Pazó (2008), "Do public subsidies stimulate private R\&D spending?", Research Policy, vol. 37, No. 3, Amsterdam, Elsevier.

Görg, H. and E. Strobl (2007), "The effect of R\&D subsidies on private R\&D”, Economica, vol. 74, No. 294, Wiley.

Hall, B.H. (1993), "R\&D tax policy during the 1980s: success or failure?", Tax Policy and the Economy, vol. 7, Cambridge, Massachusetts, National Bureau of Economic Research.

Hall, B.H. and J. Lerner (2010), "The financing of R\&D and innovation", Handbook of the Economics of Innovation, B.H. Hall and N. Rosenberg (eds.), Amsterdam, Elsevier.

Hall, B.H. and A. Maffioli (2008), "Evaluating the impact of technology development funds in emerging economies: evidence from Latin America", OVE Working Papers, No. 0108, Washington, D.C., Inter-American Development Bank.

Heckman, J.J. (1979), "Sample selection bias as a specification error", Econometrica, vol. 47, No. 1.

Hujer, R. and D. Radić (2005), "Evaluating the impacts of subsidies on innovation activities in Germany", Scottish Journal of Political Economy, vol. 52, No. 4, Scottish Economic Society.

Hussinger, K. (2003), "R\&D and subsidies at the firm level: an application of parametric and semi-parametric two-step selection models", ZEW Discussion Papers, No. 03-63, Mannheim, Centre for Economic European Research (ZEW).

Klette, T.J. and J. Moen (2012), "R\&D investment responses to R\&D subsidies: a theoretical analysis and a microeconometric study", World Review of Science, Technology and Sustainable Development, vol. 9, No. 2, Inderscience.

Lach, S. (2002), "Do R\&D subsidies stimulate or displace private R\&D? Evidence from Israel", Journal of Industrial Economics, vol. 50, No. 4, Wiley.

Lokshin, B. and P. Mohnen (2013), "Do R\&D tax incentives lead to higher wages for R\&D workers? Evidence from the Netherlands", Research Policy, vol. 42, No. 3, Amsterdam, Elsevier.

Lööf, H. and A. Heshmati (2005), "The impact of public funds on private R\&D investment: new evidence from a firm level innovation study", Discussion Papers, No. 3, Helsinki, MTT Agrifood Research Finland.

López-Acevedo, G. and H. Tan (2010), "Impact evaluation of SME programs in Latin America and the Caribbean", Washington, D.C., World Bank.

Özçelik, E. and E. Taymaz (2008), "R\&D support programs in developing countries: the Turkish experience", Research Policy, vol. 37, No. 2, Amsterdam, Elsevier.

Suetens, S. (2002), "R\&D subsidies and production effects of R\&D personnel: evidence from the Flemish region", Antwerp, University of Antwerp, unpublished.

Wallsten, S.J. (2000), "The effects of government-industry R\&D programs on private $\mathrm{R} \& \mathrm{D}$ : the case of the small business innovation research program", RAND Journal of Economics, vol. 31, No. 1, The RAND Corporation. 